\title{
THE USE OF SONGS IN IMPROVING LISTENING COMPREHENSION IN ENGLISH
}

\author{
Volkan Kahraman
}

\begin{abstract}
This study examines the use and selection of songs in listening comprehension classes. 3 students at elementary level listened to 9 songs in different genres and were asked to fill in the blanks in the lyrics provided in three listening cycles. The best comprehended songs were in acoustic soft rock and soft rock genre. The fin-dings suggest that the clarity of pronunciation and the low density of instrumentation are key factors in increasing listening comprehension. On the other hand, the origin of the singer does not seem to affect the comprehension. Analysis of songs in more varied genres may contribute to the field.
\end{abstract}

Key words: listening, music, genre, songs

\section{İNGILIZCE DINLEME BECERISININN GELIŞTIRILMESINDE ŞARKI KULLANIMI}

\section{$\ddot{O z e t}$}

Bu çalışmada dinleme sınıflarında şarkı kullanımı ve seçimi konusu incelenmektedir. Başlangıç seviyesindeki 3 öğrenciye farklı türlerde 9 şarkı dinletilmiş ve şarkı başına 3 dinleme ile sözlerde bırakılan boşlukları doldurmaları istenmiştir. En iyi anlaşılan şarkılar akustik soft rock ve soft rock türlerindeki şarkılar olmuştur. Bulgulara gore telaffuzun netliğinin ve enstrüman yoğunluğunun azliğının anlamayı artıran etmenler arasında olduğu görülmektedir. Öte yandan, solistin milliyetinin anlamada bir etkisi olmadı̆̆ı görülmektedir. Farklı türlerdeki daha fazla şarkı analizi alana katkıda bulunabilir.

Anahtar sözcükler: dinleme, müzik, tür, şarkı 


\section{INTRODUCTION}

As teachers of English as a foreign language, we teach listening skills through songs at times both as a part of our method and due to demands of students to spice up the course content. Medina suggests that

"[...] the literature abounds with the positive statements regarding the efficacy of music as a vehicle for first and second language acquisition. It has been reported to help second language learners acquire vocabulary and grammar, improve spelling and develop the linguistic skills of reading, writing, speaking and listening" (Medina, 2002: 1).

"Through songs, students discover the natural stretching and compacting of the stream of English speech" (Lems, 2001). Listening to songs has been proven to be beneficial in terms of psychology as well. "Songs add to the curriculum the oftenneglected dimension of "rightbrain" activities, to help the learner utilize another approach to process and internalize the meaning of new sounds and structures being learned" (Purcell, 1992).

"The most commonly applied procedure in this task is 'fill in the blanks' activity. Whitaker has a threestep process for this activity that she has found successful:

(1) Students hear the entire song twice; (2) the song is played a third time with a pause after each line to give the students time to write; and (3) the song is played a final time in its entirety to allow students to check what they have written" (Purcell, 1992).

This exploratory study aims to find out the parameters affecting the listening comprehension in a song listening activity. Specifically, the study aims to investigate the following issues: (1) what music genre and which singer origin are to be selected over the others for better comprehension, (2) what is the ideal qualitative and quantitative blanking and (3) should the song be listened with or without pauses.

\section{METHODOLOGY}

\section{Material}

This activity is likely to be affected by the type of music. Since the activity is to take place within a classroom setting, it is difficult to select songs which appeal to everyone. However, it is also possible to set some criteria based on the studies in the literature and our own experiences. As Purcell (1992) suggests,

"The 'staying power' of such songs is ephemeral, since they go out of fashion so quickly. The teacher who has a successful lesson with a current song one year 
may be surprised to find that in just a year's time the next group of students will disdain it as an 'oldie'."

Therefore, "it is also wise to introduce a variety of song types, thus enabling the students themselves to make more educated choice of the type of songs they will want to sing" (Purcell 1992). Lems (2001) supports this suggestion by expressing that students are often strongly motivated to learn the lyrics of a new pop song or an old favorite they have heard and never understood, so their choices for classroom music should not be overlooked. Three suggestions by Lems (1996) and Poppleton (2001) could be taken into consideration for song selection:

1. Song lyrics should be clear and loud, not submerged in the instrumental music.

2. The vocabulary load for the song should be appropriate to the proficiency level. For example, Led Zeppelin's "Stairway to Heaven" (1971) -with its vivid imagery and possibilities for multiple interpretations- might be successful with an advanced level class. With other learners, however, its fast pace, obscure references, and lack of repetition could prove troublesome, as could the word inversion in lines such as, "There walks a lady we all know."

3. Songs should be pre-screened for potentially problematic content, such as explicit language, references to violent acts or sex, or inappropriate religious allusions (Lems, 2001).

This study exercised mostly soft rock songs and old pop songs for the purpose of reducing the students' likelihood of encountering them before. Another advantage of rock songs is that it has more meaningful content and more words due to lack of repeated parts. As Moi (1994) points out, "even when not related to literary works, rock lyrics themselves can be considered poems". She further argues that rock lyrics are:

- highly motivating

- relevant to students' lives

- a potential bridge leading to more serious (i.e. "consecrated) literature

- a source of easy-to-get authentic reading and listening material (particularly in an EFL situation)

In order to identify the songs which are better understood by the students, songs of different genres were offered as listening tasks one each day. 9 songs were exercised in this respect in class during the period of teaching (See Appendix for the 
songs used). 7 of these songs were slow rock songs with which the students were not familiar. The other two songs were in pop genre; however, they did not know the lyrics to those songs, either. 4 of the singers are American, 2 are German, 1 is Canadian, 1 is Swedish and 1 is English.

\section{Subjects}

This study was carried out in a private English class with three students who were all at elementary level.

\section{Procedure}

First of all, the song lyrics were typed on computer and some words were removed. The removed words were mostly function words such as determiners, pronouns, auxiliary verbs and quantifiers as well as some of the content words they knew well but were not used to recognize within the flow of speech. The lyrics with the blanks were then handed out to the students. All songs were played in the classroom twice or three times depending on the availability of time out of a laptop computer with extra speakers attached. The songs were played three times: First, without pauses, the second time with pauses and the third time without pauses again.

After the students have listened to all the songs, the papers were checked to see how many blanks have been left unfilled. Verbal comments were also taken so as to determine the difficulty level of the songs.

\section{Oral Interview}

After the listening process, the students were interviewed orally about the activity and matters on comprehension. Given the fact that the students were at elementary level, the interview was conducted in Turkish.

\section{RESULTS AND DISCUSSION}

Listening -1 . In the first lesson the students listened to the Song- 1 sung by a German singer in acoustic/soft rock genre. The song has 205 words in total. There were 44 blanks only 8 of which were content words. The first listening was without pauses and the second one was with pauses. They could find approximately $\% 75$ of the words. After that, they listened to the song for the third time just to read it as a whole.

Listening -2. In the second lesson another song sung by a German singer in soft rock genre with 152 words was played. This time there were 37 blanks 4 of which 
were content words. The song was listened to three times and then the success rate was checked. It was around $\% 85$ this time.

Listening - 3. After two soft rock songs, I decided to play an easier song in the pop genre. It was sung by an American singer and was a very slow song. There were 32 blanks in the lyrics out of 167 words in total and 8 of them were content words. They had more difficulty than before. Although the song was the slowest of all and in the pop genre, the rate of success was about $\% 50$.

Listening -4 . In the fourth listening, I chose a shorter soft rock song sung by a Swedish singer with 157 words. Since the words in the song were not easy ones, and the pronunciation was not so clear, only 16 blanks 6 of which were content words were provided. The instruments in this song were louder than other ones which made comprehension more difficult. The results were not far from expected. Despite the fact that very few words were omitted, only about less than $\% 50$ of them were comprehended.

Listening -5 . In the fifth listening session, I chose an acoustic soft rock song which sounded like a poem with very little instruments in the background. It was sung by an American singer. The song had 252 words and there were 32 blanks in the lyrics 6 of which were content words. The success rate was around $\% 90$. This was due to clear pronunciation of the singer and the low instrumental density in the background.

Listening -6 . This sixth song was a high-tempo rock song with a faster flow of lyrics. It was sung by a Canadian singer. The instrumentation was loud but the singer's voice and pronunciation was clear. There were 214 words in the song and 25 blanks, 11 of which were content words. The students listened to the song three times and the success rate was around $\% 70$. The relative speed of the song when compared to others did not seem to have affected the comprehension much.

Listening -7 . The seventh song was a slow soft rock song with 221 words sung by an American singer. There were 23 blanks 5 of which were content words. The song was very slow and the pronunciation was clear. The instrumentation was not loud and it made comprehension easier. The success rate was around $\% 75$.

Listening -8 . The eighth song was a short soft rock song with 127 words. The singer was British. There were 14 blanks and 3 of them were content words. The success rate was around $\% 80$.

Listening -9 . The last song was actually a melodic singing without any instruments. It was sung by an American singer in the pop genre. Although there were no instruments, the flow of lyrics was rather fast and the song was the longest of all which they had listened to up to then. Out of 242 words in total, there were 59 blanks and 16 of them were content words. Although it was a long song, we 
listened to it three times, but the success rate was below \%60. The reason for that was that the song was rather fast and the singer's pronunciation was not very clear.

Table 1 shows the results of the study. The parameters taken into consideration are the origin of the singer, the genre, the number of total words, omitted function words, omitted content words, total omitted words and the success rate measured by checking out the students' papers after listening.

Table 1. Description of songs and success rate.

$\begin{array}{lllccccc} & \begin{array}{l}\text { Singer } \\ \text { Origin }\end{array} & \text { Music Genre } & \begin{array}{c}\text { Total } \\ \text { Words }\end{array} & \begin{array}{c}\text { Omitted } \\ \text { Function }\end{array} & \begin{array}{c}\text { Omitted } \\ \text { Content }\end{array} & \begin{array}{c}\text { Total } \\ \text { Omitted }\end{array} & \begin{array}{c}\text { Success } \\ \text { Rate }\end{array} \\ \text { Song -1 } & \text { German } & \text { Acoustic Soft Rock } & 205 & 36 & 8 & 44 & 75 \\ \text { Song -3 } & \text { American } & \text { Pop } & 167 & 24 & 8 & 32 & 50 \\ \text { Song -4 } & \text { Swedish } & \text { Soft Rock } & 157 & 10 & 6 & 16 & 50 \\ \text { Song -5 } & \text { American } & \text { Acoustic Soft Rock } & 252 & 26 & 6 & 32 & 90 \\ \text { Song -6 } & \text { Canadian } & \text { Rock } & 214 & 14 & 11 & 25 & 70 \\ \text { Song -7 } & \text { American } & \text { Soft Rock } & 221 & 18 & 5 & 23 & 75 \\ \text { Song -8 } & \text { British } & \text { Soft Rock } & 127 & 11 & 3 & 14 & 80 \\ \text { Song -9 } & \text { American } & \text { Pop } & 242 & 43 & 16 & 59 & 60\end{array}$

As seen in Table 1, during the applications different success rates across the songs have been observed. The success rate is the highest in the $5^{\text {th }}$ song, which is an acoustic soft rock song sung by an American singer. Surprisingly, it is also the song that has the largest number of words. According to the results, the origin of the singer does not seem to have a significant effect on comprehension success. The findings of the study and the oral interviews with the students indicate that it is the clarity of pronunciation and the music in the background that matter the most.

This finding is in parallel with Purcell's view on the difficulty of the songs to be chosen.

"The relative difficulty of the song, either from the point of view of its melody or its lyrics, must be weighed against the level of ability of the class, as well as the teacher's own insight about how "musical" a class may be" (Purcell, 1992).

The activity seems to be strongly affected by the clarity of the pronunciation of the songs and the singer.

Figure 1 shows the success rates across the songs from top to bottom. 
Figure 1. The success rates across the songs.

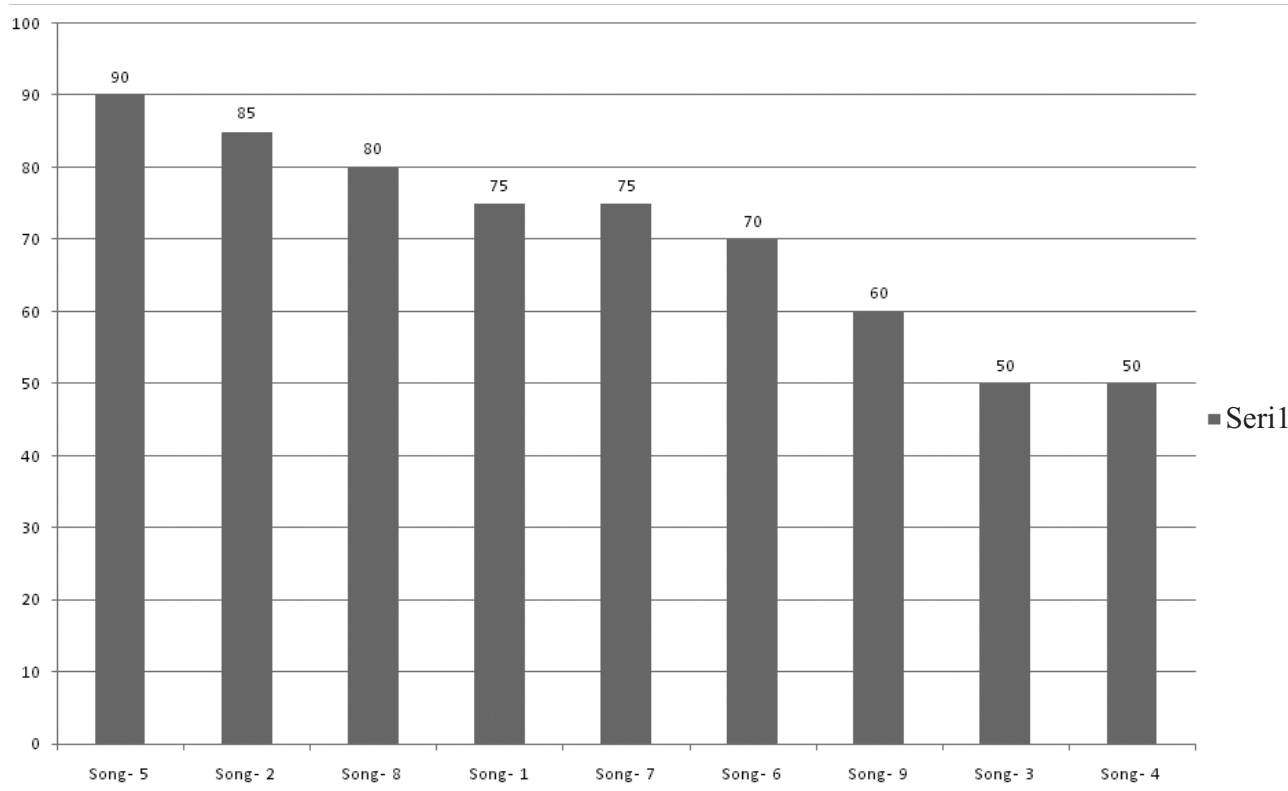

The figure clearly indicates that the top-three success rates are in the songs sung by American, German and British singers respectively. These songs are also in acoustic soft rock and soft rock genre. The pop songs, on the other hand, are in the bottom-three in terms of comprehension.

\section{The Oral Interview}

All the three students liked to listen to songs in the class and they also liked the songs played. However, they did not think that they could understand all the lyrics in the songs. They all thought that the songs were catchy and two of them stated that they listened to the songs outside the class as well. They thought that it was quite easy to fill in the blanks in the song lyrics and two of them agreed that the missing words were those which had been studied in the class earlier. They believed that they could find the missing words from the context even if they could not fully hear it. All students thought that it was useful to listen to songs in the classes and the time spared for this activity was sufficient.

As regards the number of listenings, two of the students thought that 2 was ideal and the other student thought it should be more than once. Two of the students agreed that it was useful to listen to the songs with pauses. In terms of the ratio of 
missing vocabulary in the lyrics, two students thought that the number of missing words was normal while the other student considered them few.

\section{CONCLUSIONS}

This study indicates that the selection of singers from specific origins does not help better comprehension when compared to the clarity of the pronunciation and the instrumentation factors. The instrumentation has a considerable effect on comprehension and thus should be taken into consideration when selecting songs. The lower and the more silent the instrumentation is, the better comprehension will occur. On the other hand, selecting acoustic and/or soft rock songs could be better than pop songs, both in terms of clarity and more meaningful content.

In terms of lyrics and vocabulary, the average ratio of blanking is around $\% 15$ -20 of total words. It is better to ask all the words which are already known by the students. This can be achieved by selecting more function words over the content words. It should be noted that the blanking should be made within or at the end of the lines. Blanking the first word in the line usually leads to incomprehension.

The ideal listening cycle for a song should not exceed two times at one session. These two listening steps should better be done by fist streaming the audio without pauses and then listening for the second time with pauses. Nonetheless, the students should be encouraged to listen to those songs after the class in their free time. Further studies can be carried out with more students. Finally, as Purcell (1992) suggests, "an important caution, however, is that whatever else may be evaluated in the learning of a song, the student's own musical ability should not be judged, and students should be told this from the start".

\section{References}

Purcell, John M. 1992. Using Songs to Enrich the Secondary Class. Hispania, Vol. 75, No. 1. pp. 192-196.

Medina, Suzanne L. 2002. "Using Music to Enhance Second Language Acquisition: From Theory to Practice. Language, Literacy, and Academic Development for English language Learners. Lalas, J. \& Lee, S. Boston. Pearson Custom Pub.

Lems, Kristin. 2001. Using Music in the Adult ESL Classroom. National Center for ESL Literacy Education, Retrieved March 28, 2008 from http://www.marshalladulteducation. org/pdf/briefs2/Using_Music in the_Adult_ESL_Classroom.pdf

Moi, Claudia Monica Ferradas. 1994. Rock Poetry: The Literature Our Students Listen To. Paper presented at the Annual Meeting of the Teachers of English to Speakers of Other Languages (28 ${ }^{\text {th }}$, Baltimore, MD, March $\left.8-12,1994\right)$ 


\section{APPENDIX}

\section{THE SONGS}

Song-1: Blind Guardian. 1992. "The Bard's Song-In the Forest". Somewhere Far Beyond, Virgin Records.

Song - 2: Scorpions. 1993. "Lonely Nights". Face the Heat, Mercury Records.

Song - 3 : Nancy Sinatra. 1966. "Bang Bang (My Baby Shot Me Down)". How Does That Grab You?, Boots Enterprises, Inc. [Originally written by Sonny Bono. Originally performed by Cher. 1966. Bang Bang (My Baby Shot Me Down) Single, Imperial records.]

Song -4 : Therion. 1999. "Seawinds". Crowning of Atlantis, Nuclear Blast Records. [Originally performed by Accept. 1979. Accept, CBS Records.]

Song - 5 : Savatage. 1991. "Believe". Streets: A Rock Opera, Atlantic Records.

Song - 6: Annihilator. 1993. "Sounds Good to Me". Set the World on Fire, Roadrunner Records.

Song -7: Alice Cooper. 2005. "The Saga of Jesse Jane". "Dirty Diamonds", Eagle Rock/Spitfire Records.

Song - 8: Beatles. 1965. "Yesterday". Help, Parlophone/EMI Records.

Song - 9: Suzanne Vega. 1987. “Tom’s Diner”. Solitude Standing, A\&M Records. 